Миков Д. М., головний спеціаліст Управління праці та соиіального захисту населення м. Коростеня м. Коростень, Житомирська область, Україна DOI: https://doi.org/10.30525/978-9934-26-107-7-5

\title{
СОЦІАЛЬНО-ЕКОНОМІЧНИЙ РОЗВИТОК РЕГІОНІВ В УМОВАХ ДЕЦЕНТРАЦЗАЦЇ̈ (НА ПРИКЛАДІ МІСТА КОРОСТЕНЬ ЖИТОМИРСЬКОЇ ОБЛАСТІ)
}

Саме стимулювання розвитку територій, необхідність територіального вирівнювання, забезпечення їх фінансової спроможності, а також організаційної незалежності вимагало проведення реформи адміністративно-територіального устрою.

У ході проведення реформи адміністративно-територіального устрою 2020 року Коростенський район був укрупнений, а об'єднав такі райони Житомирської області: Коростенський, Лугинський, Малинський, Народичський, Овручський, Олевський, частину Хорошевського (Володарско-Волинського) району, 3 адміністративним центром у місті Коростень.

Метою реформи стало об'єднання територій для стимулювання їх спроможності та можливостей розвитку, перерозподіл фінансових ресурсів на користь територій, надання механізмів управління територіями та забезпечення їх спроможності.

Серед очевидних проблем, які негативно впливали на розвиток міст, сіл та селищ і територій регіонів були: територіальні диспропорції соціально-економічного розвитку (наявність територій, які активно розвивались і депресивних територій), погіршення демографічної ситуації в невеликих містах та зменшення кількості непрацездатного населення, недостатність фінансового ресурсу для розвитку територій.

Найважливішим аспектом становлення та розвитку об'єднаної територіальної громади $€$ питання створення пї майбутнього iз рівним доступом до послуг, високою якістю життя та комфортними і безпечними умовами проживання. Саме тому 
останнім часом все активніше обговорюється необхідність здійснення стратегічного планування на рівні громади.

Сталий розвиток територій забезпечується поєднанням екологічних, економічних та соціальних складових розвитку. Саме за таких умов можливе створення комфортного середовища, підвищення якості життя сільського населення.

Розглядаючи основні напрямки необхідного фінансування, представимо їх у таблиці 1 .

Таблиця 1

Пріоритетні напрямки розвитку регіону

\begin{tabular}{|c|c|c|c|c|}
\hline & $\begin{array}{l}\text { Пріори- } \\
\text { тетний } \\
\text { напря- } \\
\text { мок }\end{array}$ & Назва проскту & 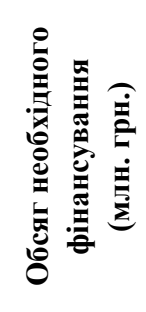 & 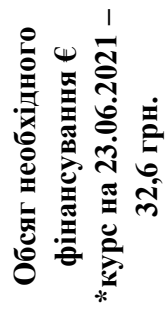 \\
\hline 1 & 2 & 3 & 4 & 5 \\
\hline \multirow{2}{*}{1} & \multirow{2}{*}{ 可 } & $\begin{array}{l}\text { Висадка зелених насаджень } \\
\text { (павловнії навколо полігону } \\
\text { твердих побутових відходів) }\end{array}$ & & \\
\hline & & $\begin{array}{c}\text { Відновлення русла річки Уж } \\
\text { (протяжність р. Уж по } \\
\text { м. Коростень }-6,7 \text { км.) }\end{array}$ & 15,0 & 460123,0 \\
\hline \multirow[b]{2}{*}{2} & \multirow{2}{*}{ 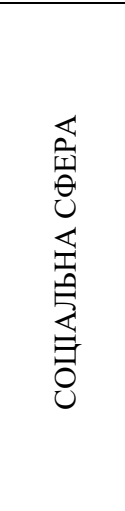 } & $\begin{array}{c}\text { Придбання низькополого транс- } \\
\text { порту для забезпечення якісним } \\
\text { обслуговуванням маломобільних } \\
\text { груп населення. Потреба в } \\
\text { оновленні складає } 12 \text { автобусів }\end{array}$ & 46,8 & 1435582,8 \\
\hline & & $\begin{array}{c}\text { Встановлення автоматичної } \\
\text { системи обліку оплати проїзду в } \\
\text { громадському транспорті (вартість } \\
\text { проекту залежить від технічного } \\
\text { завдання. Та високі відсотки } \\
\text { банківських послуг здорожують } \\
\text { вартість проїзду, що стримує } \\
\text { розвиток даної послуги в Україні) }\end{array}$ & $\begin{array}{c}\text { Розра- } \\
\text { хунок для } \\
\text { кожного } \\
\text { міста } \\
\text { визна- } \\
\text { чається } \\
\text { окремо }\end{array}$ & \\
\hline
\end{tabular}


Продовження Таблиці 1

\begin{tabular}{|c|c|c|c|c|}
\hline 1 & 2 & 3 & 4 & 5 \\
\hline & & $\begin{array}{c}\text { Створення ресурсного простору } \\
\text { для дітей з особливими освітніми } \\
\text { потребами (ООП) та їх родин, } \\
\text { облаштування дитячого } \\
\text { майданчику на території } \\
\text { КУ «Коростенський ІРЦ» } \\
\text { Коростенської територіальної } \\
\text { громади Житомирської області. }\end{array}$ & 1,2 & 36810,0 \\
\hline & & $\begin{array}{c}\text { Розвиток велосипедної } \\
\text { інфраструктури міста } \\
\text { (влаштування велодоріжок, } \\
\text { популяризація використання } \\
\text { альтернативного виду транспорту } \\
\text { (велосипедів, електросамокатів) }\end{array}$ & 2,5 & 76687,1 \\
\hline & & $\begin{array}{c}\text { Встановлення пандусів } \\
\text { (ціна за } 1 \text { пандус - від 50,0 до } \\
\text { 120,0 тис.грн., середня вартість - } \\
\text { 85,0 тис.грн.) } \\
\end{array}$ & & \\
\hline & & $\begin{array}{c}\text { Встановлення «розумних» зупинок } \\
\text { (електронне табло, інтернет, } \\
\text { засоби підзарядки, відеоспосте- } \\
\text { реження, рекламний банер). } \\
\text { В місті налічується близько } 200 \\
\text { зупинок громадського транспорту. } \\
\text { Всі зупинки не відповідають } \\
\text { технічним вимогам сучасності. } \\
\text { Вартість однієї «Розумної } \\
\text { зупинки» від } 6,0 \text { до 8,0 тис.євро) } \\
\end{array}$ & & \\
\hline 3 & 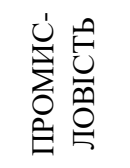 & $\begin{array}{c}\text { Створення умов та робочих місць } \\
\text { (1000 осіб) на території } \\
\text { Індустріального парку } \\
\text { «Коростень» }\end{array}$ & 515,0 & 15797546,0 \\
\hline 4 & 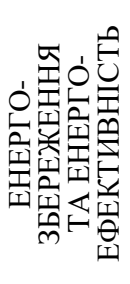 & $\begin{array}{c}\text { Реконструкція мереж зовнішнього } \\
\text { освітлення (реконструкція мереж, } \\
\text { встановлення апаратури } \\
\text { регулювання включення- } \\
\text { виключення з можливістю } \\
\text { автоматичного регулювання } \\
\text { світлового потоку) }\end{array}$ & 16,2 & 496632,5 \\
\hline
\end{tabular}




\begin{tabular}{|c|c|c|c|c|}
\hline & & & \multicolumn{2}{|c|}{ Продовження Таблиці 1} \\
\hline 1 & 2 & 3 & 4 & 5 \\
\hline & & $\begin{array}{c}\text { Термомодернізація муніципальних } \\
\text { будівель установ та організацій } \\
\text { (дошкільні та шкільні заклади) }\end{array}$ & 82,6 & 2533742,3 \\
\hline 5 & 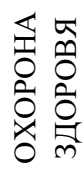 & $\begin{array}{l}\text { Будівництво Хірургічного корпусу } \\
\text { на території центральної лікарні }\end{array}$ & 87,8 & 2693251,5 \\
\hline 6 & 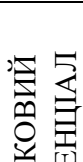 & $\begin{array}{c}\text { Створення навчально-практичного } \\
\text { центру (smar-майданчик) на базі } \\
\text { професійного ліцею } \\
\text { (350 учнів) }\end{array}$ & 19,0 & 582822,1 \\
\hline & 艺它 & $\begin{array}{c}\text { Відкриття STEM - лабораторії на } \\
\text { базі академічного ліцею } \\
\text { (350 учнів) }\end{array}$ & 12,0 & 368098,2 \\
\hline
\end{tabular}

Враховуючи зазначене вище, ми бачимо, що управлінці в місті Коростень визначились 3 пріоритетними напрямками i мають чітке усвідомлення що необхідно для реалізації зазначених проєктів. Кожна стаття витрат має розрахунки щодо необхідного фінансування.

Разом 3 тим, триває розробка стратегічного плану розвитку Коростенської міської територіальної громади до 2030 року. Дана концепція має враховувати оцінку соціально-економічного стану громади та перспектив іiї розвитку.

На даний час діє Програма підтримки малого та середнього підприємництва в місті Коростені на 2020-2024 роки. Програма визначає основні шляхи реалізації на місцевому рівні державної політики розвитку підприємництва і спрямована на ефективне партнерство влади та бізнесу. Основними напрямами діяльності визначено:

- впорядкування нормативно-правового регулювання підприємницької діяльності;

- удосконалення системи інформаційної підтримки та забезпечення консультативних послуг; 
- розширення можливостей доступу суб'єктів малого i середнього підприємництва до фінансово-кредитних ресурсів;

- сприяння розвитку інфраструктури підтримки малого i середнього підприємництва;

- запровадження системи організаційно-освітніх заходів, спрямованих на підвищення фахового рівня, знань, навичок суб'єктів господарювання, щодо ведення бізнесу, поширення серед населення правових та економічних знань, необхідних для здійснення підприємницької діяльності.

Для забезпечення підтримки діючого бізнесу та тих, хто хоче започаткувати власну справу в місті працює Центр підтримки підприємництва, який надає безкоштовну інформаційноконсультативну допомогу.

Таким чином, всебічне залучення інвестицій та створення сприятливих умов для ведення бізнесу стануть основним підгрунтям для проведення якісних та необхідних реформ, які поліпшать економічно-соціальний рівень регіону, та підвищать інвестиційну привабливість. Крім того, участь у державних програмах фінансування проєктів розвитку та участь у програмах міжнародних організацій дають можливість залучення додаткових коштів.

\section{Література:}

1. Закону України «Про інвестиційну діяльність» : закон України від 18 верес. 1991 р. № 1560-XII [із змінами станом на 13.02.2021 p.]. URL: https://zakon.rada.gov.ua/laws/show/1560-12\#Text.

2. Пальчук В. Розвиток економічного потенціалу громад у рамках реформи 3 децентралізації. Україна: події, факти, коментарі. 2018. № 11. С. 38-50.

3. Територіальні громади в умовах децентралізації: ризики та механізми розвитку: монографія / за ред. Кравціва В.С., Сторонянської І.З. Львів: ДУ «Інститут регіональних досліджень імені М.І. Долішнього» НАН України, 2020. $531 \mathrm{c}$. 